\title{
Cowpea Cover Crop Mulch for Weed Control in Desert Pepper Production
}

\author{
Chad M. Hutchinson and Milton E. McGiffen, Jr. ${ }^{1}$ \\ Department of Botany and Plant Sciences, University of California, Riverside, \\ CA 92521-0124
}

Additional index words. Capsicum annuum, vegetable production, Vigna unguiculata, sustainable, organic, Coachella Valley

\begin{abstract}
A 2-year field project was conducted in Thermal, Calif., to investigate cowpea [Vigna unguiculata (L.) Walp.] mulch as an alternative weed control option in pepper (Capsicum annuum L.) production. Treatments included: bare ground (BG) with hand weeding, BG with no weeding, cowpea mulch $(C M)$ with hand weeding, and $C M$ with no weeding. Cowpea was seeded in July on $76-\mathrm{cm}$ beds and irrigated with buried drip line. Two weeks prior to transplanting peppers, irrigation water was turned off to desiccate the cowpea plants. In September, cowpea was cut at the soil line, mulch was returned to the top of the bed, and pepper plants were transplanted into the mulch and fertilized through the drip line. Every 2 weeks, the number of weeds emerged and pepper plant height were recorded. Fruit production, pepper plant dry weight, and weed dry weight were recorded at harvest in December. Fewer weeds emerged in CM than in BG. The final weed population in nonweeded $\mathrm{CM}$ was reduced $80 \%$ and $90 \%$ in comparison with nonweeded BG in 1997 and 1998, respectively. Weed dry weights in nonweeded CM were $67 \%$ and $90 \%$ less than those in nonweeded BG over the same period. In 1997 and 1998, respectively, pepper plants produced $202 \%$ and $156 \%$ more dry weight, as well as greater fruit weight, in CM than in BG. There were no differences in mean fruit weight. Cowpea mulch provided season-long weed control without herbicides while promoting plant growth and fruit production.
\end{abstract}

The desert valleys of Southern California produce a myriad of vegetables with a limited number of herbicides available for weed control (Mayberry et al., 1995). The Food Quality Protection Act mandates a review of pesticide use in all crops and threatens to further reduce the number of available herbicides (Greenleaf, 1999). If herbicides are lost, weed control alternatives will be needed. The only option currently available is hand weeding, which is often one of the costlier components of vegetable production (Mayberry et al., 1995).

Cover crop mulches are a potential weed control alternative available to both conventional and organic growers. Cover crops have been used to reduce soil erosion; add nitrogen to the soil as a green manure; and conserve soil water during hot, dry periods of the growing season (Abdul-Baki and Teasdale, 1993; Nelson et al., 1991; Wagner-Riddle et al., 1994). To be acceptable for use in desert vegetable production systems, cover crop growth must fit into current production schedules. Vegetables are generally not grown in the low desert from July through August; thus, this late-summer fallow period could be used for cover crop production. However, any potential cover crop must be capable of growth in

Received for publication 8 Mar. 1999. Accepted for publication 16 July 1999 . We thank Vince Samons and Lynn Morrison at the Coachella Valley Agricultural Research Station for their work on the project. The cost of publishing this paper was defrayed in part by the payment of page charges. Under postal regulations, this paper therefore must be hereby marked advertisement solely to indicate this fact.

${ }^{1}$ To whom reprint requests should be addressed; e-mail:milt@ucrac1.ucr.edu. the intense summer heat of the desert.

Cowpea (Southern pea) is adapted to growth in hot, dry climates (Craufurd et al., 1997; Littleton et al., 1979) and has traditionally been used worldwide for both seed production (e.g., harvested as blackeyed pea) and as a green manure because of its abundant biomass production (Power and Koerner, 1994). Use of cowpea cover crop as mulch on the soil surface could reduce weed emergence and grower dependence on herbicides.

Both conventional and organic growers could benefit from information on alternative production systems that incorporate cowpea mulches for weed control. In desert production systems, the majority of peppers are grown on beds fumigated with methyl bromide and covered with black plastic mulch. As the phaseout date of 2005 for methyl bromide use approaches, growers will need to switch to alternative production systems (United Nations Environment Programme, 1997). For organic growers, a methyl bromide-black plastic mulch system for vegetable production is not an option. However, use of cowpea cover crop mulch for weed control in organic vegetable production systems would be acceptable. The objectives of this research were to determine the influence of cowpea mulch on season-long weed control, pepper plant growth, and fruit production.

\section{Materials and Methods}

A 2-year trial was conducted at the Coachella Valley Agricultural Research Station in Thermal, Calif. Pepper production treatments included: bare ground (BG) with hand weeding, BG with no weed control, cowpea mulch (CM) with hand weeding, and CM with no weed control. Treatments were arranged in a randomized complete-block design with four replications on $76-\mathrm{cm}$ beds. Each experimental unit was a 6.1-m length of bed. The soil type was a Carsetas loamy sand $(28 \%$ sand, $61 \%$ silt, $11 \%$ clay, $0.45 \%$ organic matter, $\mathrm{pH} 7.3$ ). Drip tape was buried $10 \mathrm{~cm}$ deep in each bed to irrigate both cowpea and the following pepper crop. 'Iron Clay' cowpea was seeded in mulch plots on 7 July 1997 and 10 July 1998 as double rows on each bed with $2.5-\mathrm{cm}$ seed spacing within each row and $20 \mathrm{~cm}$ between rows. Irrigation was stopped 2 weeks prior to transplanting pepper.

On the day pepper plants were transplanted, cowpea was cut by hand at the soil surface and plants placed intact on the bed surface. Sixweek-old 'Keystone' bell pepper plants were transplanted with $30.5 \mathrm{~cm}$ between plants on 2 Sept. 1997 and 22 Sept. 1998. In 1997 and 1998, peppers were side-dressed at transplanting with $15 \mathrm{~N}-6.6 \mathrm{P}-12.5 \mathrm{~K}$ pelletized fertilizer $\left(112 \mathrm{~kg} \cdot \mathrm{ha}^{-1}\right)$. Six weeks after transplanting, peppers were fertilized through the irrigation line with $15 \mathrm{~N}-6.6 \mathrm{P}-12.5 \mathrm{~K}$ fertilizer (17 $\left.\mathrm{kg} \cdot \mathrm{ha}^{-1}\right)$. Peppers were harvested on $18 \mathrm{Dec}$. 1997 and 15 Dec. 1998.

Cowpea biomass was collected from $1 \mathrm{~m}$ of bed when the pepper plants were transplanted and at final harvest each year. The cowpea tissue was oven-dried at $70{ }^{\circ} \mathrm{C}$ for $4 \mathrm{~d}$ or until a constant dry weight was obtained. Weed emergence, pepper plant height, and number of fruit were recorded at transplanting and at 2-week intervals until harvest. The BG and $\mathrm{CM}$ treatments were weeded by hand every 2 weeks to maintain weed-free plots during the season. Weeds emerged from $1 \mathrm{~m}$ of bed in the nonweeded treatments were counted. Pepper plant height was measured from soil level to the last emerged leaf. At harvest, 10 plants from within each plot were removed and dried as described above. Dry weight was recorded without including fruit weight. Fruit were removed, counted, and weighed prior to drying. Weight of marketable and total fruit were recorded. Fruit were considered marketable if they were unblemished and weighed over $40 \mathrm{~g}$. Fruit production data could not be combined over years because of reduced production in 1997, but the trends in production were similar in both years.

Plant height and the yield data were initially analyzed using $2 \times 2$ factorial analysis with the presence or absence of cowpea mulch and weeding or nonweeding as the two factors. The only factor that was significant was the presence or absence of cowpea mulch. The weeding factor and the interaction were not significant for any of the parameters tested. Therefore, all data were analyzed with the SAS analysis of variance procedure (SAS Institute, 1993), and the means were separated with Fisher's protected LSD.

\section{Results and Discussion}

At pepper plant transplanting, cowpea dry weight was 610 and $713 \mathrm{~g} \cdot \mathrm{m}^{-1}$ bed in 1997 and 
Table 1. Cowpea mulch biomass in 1997 and 1998 and the percent reduction in biomass over the season.

\begin{tabular}{lccc}
\hline & \multicolumn{3}{c}{ Dry wt of mulch $\left(\mathrm{kg} \cdot \mathrm{ha}^{-1}\right)$} \\
\cline { 2 - 4 } & $\begin{array}{c}\text { At pepper } \\
\text { Year }\end{array}$ & $\begin{array}{c}\text { At pepper } \\
\text { transplanting }\end{array}$ & $\begin{array}{c}\text { Reduction } \\
\text { harvest }\end{array}$ \\
\hline 1997 & 8227 & 3885 & 52.8 \\
1998 & 9618 & 2441 & 74.6 \\
\hline
\end{tabular}

1998, respectively; this is equivalent to 8227 and $9618 \mathrm{~kg} \cdot \mathrm{ha}^{-1}$, respectively (Table 1 ). The cowpea cover crop was cut before seedpods were mature to prevent seeding in the pepper crop. Cutting the cowpea at the soil surface was sufficient to reduce cowpea regrowth for the duration of the experiment without the need for herbicides. Regrowth did not interfere with growth of the pepper plants. In a fullscale production system, the cowpea could be cut effectively with a sickle-bar mower at the plant base and the litter thrown on top of the bed.

In both seasons, $\mathrm{CM}$ reduced weed populations significantly at 3, 5, and 9 weeks after transplanting (Table 2). At harvest, the number of weeds emerged in the CM nonweeded plots was reduced by $80 \%$ and $90 \%$ of the number in the BG plots in 1997 and 1998, respectively.

In 1997 and 1998, weed dry weights in nonweeded CM plots were $67 \%$ and $90 \%$ less, respectively, than those in similar BG plots (Table 3). The mean weight per weed was greater in nonweeded CM than in the nonweeded BG plots in 1997, but the reverse was true in 1998 (Table 3). In general, fewer weeds emerged in nonweeded CM plots than in the nonweeded BG plots.

Weed control by cover crops has been attributed to both an allelopathic (Barnes et al., 1987) and physical influence of mulch on the soil surface (Creamer et al., 1996). Traditionally, crops that release allelochemicals have been planted in temperate climates where rainfall leaches the chemicals from the cover crop, allowing them to influence weed seed germination and growth. Our experiments were conducted in the desert, and rainfall was limited during the duration of the experiment. All irrigation was applied through buried drip tape that minimally wets the bed surface. Drip irrigation should minimize leaching of allelochemicals. Weed control by CM in our research was a result of the physical effect of mulch on the soil surface. A mulch can control weeds by reducing the light at the soil surface to levels insufficient for the germination of many weed species (Teasdale and Mohler, 1993).

Mulch also reduces diurnal temperature flux by reducing the solar energy reaching the soil surface during the day and insulating against radiant heat loss at night. Seeds of many weeds, such as Portulaca oleracea L., require a temperature flux of $15^{\circ} \mathrm{C}$ to break dormancy (Thompson and Grime, 1983). Additionally, the germination of Chenopodium album L. and Amaranthus retroflexus L. are temperature-dependent, with high soil temperatures favoring germination (Wiese and Binning, 1987). Under mulch, maximum soil

Table 2. Effects of cowpea mulch on noncumulative weed emergence in nonweeded plots.

\begin{tabular}{|c|c|c|c|c|c|c|c|c|}
\hline \multirow{3}{*}{$\begin{array}{l}\text { Soil } \\
\text { treatment }\end{array}$} & \multicolumn{6}{|c|}{ Time after transplanting (weeks) } & & \\
\hline & \multicolumn{2}{|c|}{3} & \multicolumn{2}{|c|}{5} & \multicolumn{2}{|c|}{9} & \multicolumn{2}{|c|}{ Harvest } \\
\hline & 1997 & 1998 & 1997 & 1998 & 1997 & 1998 & 1997 & 1998 \\
\hline & \multicolumn{8}{|c|}{ weeds per meter of bed } \\
\hline Cowpea mulch & $14 \mathrm{a}^{\mathrm{z}}$ & $8 \mathrm{a}$ & $26 \mathrm{a}$ & $8 \mathrm{a}$ & $16 \mathrm{a}$ & $8 \mathrm{a}$ & $48 \mathrm{a}$ & $10 \mathrm{a}$ \\
\hline Bare ground & $299 \mathrm{~b}$ & $142 \mathrm{~b}$ & $211 \mathrm{~b}$ & $121 \mathrm{~b}$ & $200 \mathrm{~b}$ & $85 \mathrm{~b}$ & $244 \mathrm{~b}$ & $111 \mathrm{~b}$ \\
\hline
\end{tabular}

${ }^{2}$ Mean separation within columns by LSD, $P<0.05$.

Table 3. Effect of cowpea mulch on total weed dry weight and mean weight per weed at harvest in nonweeded plots.

\begin{tabular}{|c|c|c|c|c|}
\hline \multirow{2}{*}{$\begin{array}{l}\text { Soil } \\
\text { treatment }\end{array}$} & \multicolumn{2}{|c|}{$\begin{array}{c}\text { Total dry wt } \\
\left(\mathrm{g} \cdot \mathrm{m}^{-1} \text { bed }\right)\end{array}$} & \multicolumn{2}{|c|}{$\begin{array}{l}\text { Mean wt per weed } \\
\text { (g/plant) }\end{array}$} \\
\hline & 1997 & 1998 & 1997 & 1998 \\
\hline Cowpea mulch & $12.2 \mathrm{a}^{\mathrm{z}}$ & $7.0 \mathrm{a}$ & $0.39 \mathrm{a}$ & $0.45 \mathrm{a}$ \\
\hline Bare ground & $37.1 \mathrm{~b}$ & $72.1 \mathrm{~b}$ & $0.17 \mathrm{a}$ & $1.01 \mathrm{a}$ \\
\hline
\end{tabular}

${ }^{2}$ Mean separation within columns by LSD, $P<0.05$.

temperatures, as well as soil temperature flux, may be reduced, thus creating suboptimum conditions for weed seed germination. Although in our experiments there was no difference in weed species diversity, more weeds of all species were present in the BG than in the CM plots (Table 2). The predominant species were Cyperus rotundus L., P. oleracea, A. retroflexus, and C. album.

Pepper plants grown in CM were generally taller than those grown in BG in both years of the trial (Table 4). However, in 1997, plants in the BG plots were larger at 9 WAT than plants in the CM plots. In 1998, at the 5 and 7 WAT measurements, heights were more divergent, with significantly larger plants in CM than in BG treatments. In 1997 and 1998, respectively, the plants in CM produced $202 \%$ and $156 \%$ more dry weight than did those in BG plots (Table 5).

Pepper plants in the weeded CM plots produced $182 \%$ more marketable fruit weight than did plants in weeded BG plots (Table 5). With no weeds interfering with growth, a comparison of weeded treatments demonstrates the influence of $\mathrm{CM}$ on fruit production. Plants

Table 4. Effect of soil treatment height $(\mathrm{cm})$ of pepper plants over in the 1997 and 1998 seasons.

\begin{tabular}{|c|c|c|c|c|c|c|c|c|}
\hline \multirow{3}{*}{$\begin{array}{l}\text { Soil } \\
\text { treatment }\end{array}$} & \multicolumn{6}{|c|}{ Time after transplanting (weeks) } & & \\
\hline & \multicolumn{2}{|c|}{3} & \multicolumn{2}{|c|}{5} & \multicolumn{2}{|c|}{9} & \multicolumn{2}{|c|}{ Harvest } \\
\hline & 1997 & 1998 & 1997 & 1998 & 1997 & 1998 & 1997 & 1998 \\
\hline \multicolumn{9}{|l|}{ Cowpea mulch } \\
\hline Weeded & $--^{z}$ & $20.8 \mathrm{a}^{\mathrm{y}}$ & $28.4 \mathrm{a}$ & $25.6 \mathrm{a}$ & $30.8 \mathrm{a}$ & $26.5 \mathrm{a}$ & $32.4 \mathrm{a}$ & $28.3 \mathrm{a}$ \\
\hline Nonweeded & --- & $20.8 \mathrm{a}$ & $27.0 \mathrm{a}$ & $24.4 \mathrm{ab}$ & $29.5 \mathrm{a}$ & $26.9 \mathrm{a}$ & $30.1 \mathrm{a}$ & $28.0 \mathrm{a}$ \\
\hline \multicolumn{9}{|l|}{ Bare ground } \\
\hline Weeded & --- & $18.0 \mathrm{a}$ & $20.6 \mathrm{~b}$ & $20.9 \mathrm{~b}$ & $21.9 \mathrm{~b}$ & $22.5 \mathrm{~b}$ & $24.2 \mathrm{~b}$ & $24.0 \mathrm{a}$ \\
\hline Nonweeded & --- & $19.6 \mathrm{a}$ & $19.5 \mathrm{~b}$ & $20.8 \mathrm{~b}$ & $21.1 \mathrm{~b}$ & $24.3 \mathrm{ab}$ & $26.1 \mathrm{~b}$ & $25.1 \mathrm{a}$ \\
\hline
\end{tabular}

\section{${ }^{2}$ Not recorded.}

${ }^{\mathrm{y}}$ Mean separation within columns by LSD, $P<0.05$.

Table 5. Effects of soil treatments on pepper plant dry weight in 1997 and 1998 and yield at harvest in 1998.

\begin{tabular}{|c|c|c|c|c|c|}
\hline \multirow{3}{*}{$\begin{array}{l}\text { Soil } \\
\text { treatment }\end{array}$} & & & \multicolumn{3}{|c|}{ Fruit } \\
\hline & \multicolumn{2}{|c|}{ Dry wt/plant (g) } & No./plant ${ }^{2}$ & $\mathrm{FW} /$ plant $(\mathrm{g})^{\mathrm{z}}$ & FW/fruit (g) \\
\hline & 1997 & 1998 & 1998 & 1998 & 1998 \\
\hline \multicolumn{6}{|l|}{ Cowpea mulch } \\
\hline Weeded & $14.7 \mathrm{a}^{\mathrm{y}}$ & $7.1 \mathrm{a}$ & $2.6 \mathrm{ab}$ & $147.9 \mathrm{a}$ & $57.2 \mathrm{a}$ \\
\hline Nonweeded & $16.3 \mathrm{a}$ & $6.5 \mathrm{a}$ & $2.7 \mathrm{a}$ & $120.9 \mathrm{a}$ & $45.4 \mathrm{a}$ \\
\hline \multicolumn{6}{|l|}{ Bare ground } \\
\hline Weeded & $9.9 \mathrm{ab}$ & $4.6 \mathrm{~b}$ & $2.1 \mathrm{ab}$ & $81.3 \mathrm{~b}$ & $44.3 \mathrm{a}$ \\
\hline Nonweeded & $5.4 \mathrm{~b}$ & $4.1 \mathrm{~b}$ & $1.7 \mathrm{~b}$ & $69.7 \mathrm{~b}$ & $42.3 \mathrm{a}$ \\
\hline
\end{tabular}

${ }^{\mathrm{z}}$ Marketable fruit only. FW $=$ fresh weight.

y Mean separation within columns by LSD, $P<0.05$.

in the nonweeded $\mathrm{CM}$ treatment produced $149 \%$ and $173 \%$ more total marketable fruit than did plants in the weeded and nonweeded BG plots, respectively. Flowering and fruit production were not delayed by $\mathrm{CM}$ treatments (data not shown). In general, plants in CM plots produced significantly more marketable fruit than did those in BG plots with no difference in fruit size (Table 5).

The major concern with using cover crops is cooling the soil to a point where crop proMasiunas et al., 1995). That does not appear to be a problem with the high temperatures and intense solar radiation associated with desert vegetable production systems. Cover crop use in more temperate climates has the disadvantage of planting the vegetable crop into the mulch after a cold winter and relatively cool spring (Teasdale and Abdul-Baki, 1995). Solar radiation and high air temperatures are necessary to warm the soil for crop growth. Therefore, a cover crop can be a disadvantage when the soil must be warmed quickly after a cold winter (Knavel and Herron, 1986; Masiunas et al., 1995). duction is delayed (Abdul-Baki et al., 1996;

HortScience, Vol. 35(2), ApriL 2000 
Alternatively, in the desert system, cowpea is planted in the warmest part of the year when air temperature can reach $46{ }^{\circ} \mathrm{C}$. When the vegetable crop is planted in the fall following a cowpea cover crop, soil temperatures are already warm enough to stimulate crop growth. Pepper plants in CM may grow more and, in turn, produce more because $\mathrm{CM}$ in a desert vegetable production system moderates soil temperature and moisture extremes over the season in comparison with a BG system. Additionally, because the mulch reduces incident solar radiation on the soil surface, the microclimate around the pepper plants may also be less extreme, thereby reducing crop stress (Wagner-Riddle et al., 1996).

In conclusion, the cowpea cover crop produced abundant biomass during the hottest months of the year when vegetable production is limited. Cowpea mulch provided seasonlong weed control without herbicides and increased bell pepper yields in comparison with a BG production system. Future research should investigate the ability of $\mathrm{CM}$ to cool the soil and, in turn, reduce temperatures in the crop canopy (Schmidt and Worthington, 1998). The use of a cover crop in the desert vegetable production system may allow growers to move the vegetable production season into the hotter summer months and/or to target earlier markets when supply may be limited and prices higher.

\section{Literature Cited}

Abdul-Baki, A.A. and J.R. Teasdale. 1993. A notillage tomato production system using hairy vetch and subterranean clover mulches. HortScience 28:106-108.

Abdul-Baki, A.A., J.R. Teasdale, R. Korcak, D.J. Chitwood, and R.N. Huettel. 1996. Fresh-market tomato production in a low-input alternative system using cover-crop mulch. HortScience 31:65-69.

Barnes, J.P., A.R. Putnam, B.A. Burke, and A.J. Aasen. 1987. Isolation and characterization of allelochemicals in rye herbage. Phytochemistry 26:1385-1390.

Craufurd, P.Q., M. Subedi, and R.J. Summerfield. 1997. Leaf appearance in cowpea: Effects of temperature and photoperiod. Crop Sci. 37:167-171.

Creamer, N.G., M.A. Bennett, B.R. Stinner, J. Cardina, and E.E. Regnier. 1996. Mechanisms of weed suppression in cover crop-based production systems. HortScience 31:410-413.

Greenleaf, C. 1999. Insider insights on '99: Industry experts look ahead in the coming year and make a few predictions. Amer. Veg. Grower 47(1):2628.

Knavel, D.E. and J.W. Herron. 1986. Response of vegetable crops to nitrogen rates in tillage systems with and without vetch and rye grass. J. Amer. Soc. Hort. Sci. 111:502-507.

Littleton, E.J., M.D. Dennet, J. Elston, and J.L. Monteith. 1979. The growth and development of cowpeas (Vigna unguiculata) under tropical field conditions. I. Leaf area. J. Agr. Sci. 93:291307.

Masiunas, J.B., L.A. Weston, and S.C. Weller. 1995. The impact of rye cover crops on weed populations in a tomato cropping system. Weed Sci. 43:318-323.

Mayberry, K.M., E.N. Natwick, R.A. Gonzalez, G.H. Holmes, C.E. Bell, and K.M. Bali. 1995. Guidelines to production costs and practices, 1994-1995, Circular 104-V, Univ. of California Coop. Ext., Imperial Co., Holtville, Calif.
Nelson, W.A., B.A. Kahn, and B.W. Roberts. 1991. Screening cover crops for use in conservation tillage systems for vegetables following spring plowing. HortScience 26:860-862.

Power, J.F. and P.T. Koerner. 1994. Cover crop production for several planting and harvest dates in Eastern Nebraska. Agron. J. 86:092-1097.

SAS Institute. 1993. SAS/ETS user's guide, vers. 6 , $2^{\text {nd }}$ ed. SAS Inst., Cary, N.C.

Schmidt, J.R. and J.W. Worthington. 1998. Modifying heat unit accumulation with contrasting colors of polyethylene mulch. HortScience 33:210 214

Teasdale, J.R. and A.A. Abdul-Baki. 1995. Soil temperature and tomato growth associated with black polyethylene and hairy vetch mulches. J. Amer. Soc. Hort. Sci. 120:848-853.

Teasdale, J.R. and C.L. Mohler. 1993. Light transmittance, soil temperature, and soil moisture under residue of hairy vetch and rye. Agron. J. 85:673-680.

Thompson K. and J.P. Grime. 1983. A comparative study of germination responses to diurnally-fluctuating temperatures. J. Appl. Ecol. 20:141-156.

United Nations Environment Programme. 1997. Report of the ninth meeting of the parties to the Montreal protocol on substances that deplete the ozone layer. Montreal, Canada, United Nations Environment Programme.

Wagner-Riddle, C., T.J. Gillespie, and C.J. Swanton 1994. Rye cover crop management impact on soil water content, soil temperature and soybean growth. Can. J. Plant Sci. 74:485-495.

Wagner-Riddle, C., T.J. Gillespie, and C.J. Swanton. 1996. Rye mulch characterization for the purpose of microclimatic modeling Agr. Forest Meteorol. 78:67-81.

Wiese A.M. and L.K. Binning. 1987. Calculating the threshold temperatures of development for weeds. Weed Sci. 35:177-179. 